\title{
Tindak Tutur Direktif dalam Bahasa Lisan pada Apoteker di Puskesmas Sukabumi
}

\author{
Alfi Khoiru An Nisa', Gigit Mujianto ${ }^{2}$ \\ Pendidikan Bahasa Indonesia, Universitas Muhammadiyah Malang \\ alfinisaaaa@gmail.com ${ }^{1}$,gigit@umm.ac.id ${ }^{2}$
}

DOI: https://doi.org/10.32528/bb.v6i2.5338

First received: 22-06-2021

Final proof received: $23-10-2021$

\begin{abstract}
ABSTRAK
Tujuan penelitian ini adalah untuk mendeskripsikan bentuk tindak tutur direktif pada bahasa lisan. Penelitian ini termasuk penelitian kualitatif, dengan pendekatan deskriptif. Sumber data yang digunakan berupa video konseling antara apoteker dan pasien yang diunduh di Youtube. Data yang digunakan adalah kutipan berupa kata atau kalimat yang terdapat dalam percakapan antara pasien dan apoteker pada saat proses konseling yang masih relevan dengan tindak tutur direktif dan bahasa lisan. Penelitian ini menggunakan teknik pengumpulan berupa mengunduh video konseling di Youtube, membuat transkripsi tuturan antara apoteker dan pasien, dan mengelompokkan kata atau bahasa dari hasil transkripsi sesuai dengan indikator penelitian tindak tutur direktif dan bahasa lisan. Hasil penelitian memuat bentuk tindak tutur direktif terdapat 4 jenis yaitu menyuruh dengan tujuan meminta mitra tutur untuk melakukan sesuatu, memohon dengan tujuan meminta mitra tutur melakukan sesuatu akan tetapi meminta dengan disertai rasa hormat, menyarankan dengan tujuan memberikan saran atau anjuran kepada mitra tutur dan menasihati dengan tujuan memberikan nasihat kepada mitra tutur. Sedangkan hasil penelitian dari bahasa lisan mengenai ciri linguistiknya terdapat ciri tidak menyertakan fungsi dengan lengkap (tidak menyertakan fungsi subjek atau objek atau predikat), frasa-frasa sederhana, kalimat yang sering diulang dan bahasa yang digunakan tidak baku.
\end{abstract}

\section{Kata kunci: tindak tutur direktif; bahasa lisan; konseling apoteker}

\begin{abstract}
This study aims to describe the form of directive speech acts in spoken language. This research is a qualitative research, with a descriptive approach. The data source used is a video counseling between pharmacists and patients downloaded on Youtube. The data used are quotes in the form
\end{abstract}


of words or sentences contained in conversations between patients and pharmacists during the counseling process which are still relevant to directive speech acts and spoken language. This study uses collection techniques in the form of downloading counseling videos on Youtube, making transcriptions of speech between pharmacists and patients, and classifying words or language from the transcription results according to the directive speech act research indicators and spoken language. The results of the study contain 4 types of directive speech acts, namely ordering with the aim of asking the speech partner to do something, pleading with the aim of asking the speech partner to do something but asking with respect, suggesting with the aim of giving advice or suggestions to the speech partner and advising with respect, the purpose of providing advice to the speech partner. Meanwhile, the results of research from spoken language regarding its linguistic characteristics are that it does not include the function completely (does not include the function of the subject or object or predicate), simple phrases, sentences that are often repeated and the language used is not standard.

\section{Keywords: directive speech act; spoken language; pharmacist counseling}

\section{PENDAHULUAN}

Sebagai makhluk sosial terdapat interaksi satu sama lain antarmasyarakat berupa komunikasi dan sebagainya. Dalam komunikasi terdapat bahasa yang berperan penting di dalamnya. Setiap makhluk sosial yang berbahasa dengan tujuan komunikasi, terdapat peran tindak tutur. Tindak tutur adalah seluruh tindakan untuk mengekspresikan seluruh pikiran dan perasaan yang dilakukan oleh seseorang dengan bentuk realisasi berbicara (Apriastuti, 2017). Salah satu jenis dari tindak tutur adalah tindak tutur ilokusi yang masih terbagi menjadi 5 kelompok yaitu tindak tutur represntatif, tindak tutur komisif, tindak tutur direktif, tindak tutur ekspresif dan tindak tutur deklaratif (Purba, 2011).

Pada penelitian ini terfokus pada tindak tutur direktif. Menurut Qomariyah (2017) tindak tutur direktif adalah salah satu dari tindak tutur yang diguakan oleh penutur untuk meminta atau menyuruh orang lain atau mitra tutur untuk melakukan sesuatu hal yang menjadi keinginan penutur, hal tersebut bisa bermanfaat bagi penutur pribadi dan juga bisa bermanfaat bagi mitra tutur. Sepedapat dengan Qomariyah, Elmita et al (2013) mengatakan bahwa tindak tutur direktif adalah tindak tutur yang dilakukan oleh penutur dengan memiliki tujuan agar mitra tutur melakukan tindakan yang telah dituturkan oleh penutur sebelumnya. Selanjutnya adapun pendapat dari Arifiany et al (2016) bahwa direktif adalah tuturan yang dimaksudkan untuk membuat pengaruh agar mitra tutur melakukan tindakan, seperti memerintah, memohon dsb. Dari beberapa pendapat di atas dapat ditarik benang merah mengenai tindak tutur direktif adalah ujaran atau tuturan yang dituturkan oleh penutur kepada mitra tutur dengan maksud tertentu, maksud tersebut bisa saja dengan bentuk permintaan atau permohonan dari penutur kepada mitra tutur agar melakukan hal yang diujarkan sebelumnya. 
Tindak tutur direktif terbagi menjadi beberapa jenis yaitu berdasarkan pendapat dari Stambo \& Ramadhan (2019) menyebutkan 7 jenis tindak tutur direktif yaitu menyuruh, mengajak, meminta, memohon, menyarankan, menghimbau, dan menasehati. Besebrangan dengan pendapat Stambo \& Ramadhan, Elmita et al (2013) hanya menyebutkan 5 jenis tindak tutur direktif yaitu: menyuruh, memohon, menyarankan, menasihati dan menantang. Pendapat ketiga datang dari Sagita \& Setiawan (2020) mengatakan jenis tindak tutur direktif meliputi nasehat, perintah, pertanyaan, permintaan, penawaran, dan pemesanan. Dari ketiga pendapat di atas dapat ditarik kesimpulan bahwa tindak tutur direktif memiliki 5 jenis yang umum yaitu menyuruh, memohon, menyarankan, menasihati dan menantang.

Penggunaan tindak tutur direktif dalam kehidupan sehari-hari perlu sarana pendukung untuk melakukannya, salah satunya adalah bahasa lisan. Bahasa lisan sering kali digunakan oleh masyarakat dalam berkomunikasi satu sama lain. Bahasa lisan mempermudah komunikasi bagi penutur dan mitra tutur karena dibantu oleh aspek nonlinguistik atau faktor pendukung di luar bahasa.

Bahasa lisan adalah sesuatu yang dihasilkan oleh alat ucap dengan berisikan fonem sebagai unsur dasar dari bahasa lisan (Januar, 2014). Sedangkan menurut Aisah, S., \& Noviadi (2018) mengatakan bahwa bahasa lisaan adalah bahasa yang pengungkapannya melalui intonasi yang lengkap dan dalam pengungkapannya tidak bisa dijelaskan dalam bahasa tulis karena bahasa lisan dibantu oleh keadaan, mimik wajah dan isyarat yang dilontarkan oleh penutur atau mitra tutur. Dari penjelasan di atas dapat disimpulkan bahwa bahasa lisan merupakan bahasa yang dikeluarkan oleh alat ucap dengan pengungkapan yang dibantu oleh aspek nonlinguistik.

Bahasa lisan dapat dipastikan dengan cara mengetahui ciri linguistik dari bahasa lisan. Ciri linguistik bahasa lisan yang pertama menurut Setyawan et al. (2014) adalah unsur gramatikal tidak dinyatakan dengan lengkap (penghilangan fungsi subjek atau objek atau predikat) dan terdapat bahasa yang digunakan tidak baku. Ditambah dari Januar (2014) yaitu penggunaan frasa-frasa sederhana, penutur dan mitra tutur cenderung mengulang beberapa kalimat.

Selain melihat ciri linguistik bahasa lisan terdapat ciri nonlinguistik dari bahasa lisan yaitu berdasrkan pendapat dari Januar (2014) bahasa lisan memerlukan adanya orang lain, waktu dan ruang terikat dan juga dipengaruhi oleh intonasi yang digunakan oleh penutur atau mitra tutur. Saragih (2013) menambahkan bahwa ciri nonlinguistik bahasa lisan adalah memerlukan tambahan bahasa tubuh, dapat berlangsung tanpa alat pendukung atau property, kesalahan dalam berbicara bisa langsung dikoreksi dan dievaluasi. Dari kedua pendapat di atas dapat disimpulkan bahwa ciri linguistik dari bahasa lisan adalah seluruh unsur yang tidak memiliki kaitan dengan bahasa yang dapat diartikan dengan unsur pendukung dalam berkomunikasi dengan menggunakan bahasa lisan.

Bahasa lisan memiliki kelebihan yaitu karena adanya kehadiran mitra tutur, maka ketidakjelasan dalam pembicaraan dapat langsung ditanyakan, penggunaan bahasa lisan memiliki kejelasan karena penutur dan mitra tutur menggunakan bantuan unsur nonlinguistik, menggunakan bahasa lisan juga akan lebih cepat proses penagkapan makna 
karena mitra tutur bisa langsung melihat ekpresi atau reaksi yang diberikan oleh penutur, bahasa lisaan juga masih bisa digunakan meskipun dalam kondisi gelap, dan kelebihan terakhir dari bahasa lisan adalah lebih efisien karena banyak yang dapat diungkapkan dengan waktu yang singkat dan juga tidak engeluarkan banyak tenaga (Setyawan et al., 2014).

Dibalik kelebihan pasti terdapat kekurangan dari bahasa lisan yaitu berdasarkan pendapat dari tidak semua orang dapat menggunakan bahasa lisan, aturan yang ada pada bahasa dilakukan secara tidak formal (Januar, 2014).

Uraian di atas sudah cukup membahas tentang tindak tutur direktif, bentuk tindak tutur direktif, bahasa lisan dan ciri linguistik bahasa lisan. Dalam penelitian ini akan dilakukan penelitian tindak tutur direktif pada bahasa lisan yang digunakan oleh apoteker dan pasien pada saat konseling di puskesmas Sukabumi.

Penelitian ini bukan penelitian pertama dilakukan mengenai jenis tindak tutur direktif dan bahasa lisan melainkan pada sebelumnya sudah ada penelitian yang dilakukan. Terdapat penelitian sebelumnya yang dilakukan oleh Suryatin (2018) yang meneliti Tindak Tutur Direktif Bahasa Indonesia pada Poster Kesehatan di Puskesmas Kota Banjarbaru, hasil penelitian berupa temuan jenis tindak tutur direktif pada poster kesehatan yang dikeluarkan oleh puskesmas terdapat 5 tindak tutur direktif yaitu permintaan, pertanyaan, larangan, persyaratan, dan nasihat. Dan makna perwujudan dari poster yang dikeluarkan mengandung makna perintah, imbauan desakan, ajakan, dan larangan. Persamaan penelitian yang dilakukan oleh Suryatin dan penelitian ini adalah teori tindak tutur direktif dengan objek puskesmas, sedangkan perbedaan penelitian ini dengan penelitian yang akan dilakukan adalah penelitian ini mengambil data dari tulisan atau poster.

Penelitian lainnya juga dilakukan oleh Yuliarti et al. (2015) yang meneliti Tindak Tutur Direktif Dalam Wacana Novel Trilogi karya Agustinus Wibowo, dengan hasil penelitian berupa jenis tindak tutur yang ditemukan adalah fungsi mengajak, perintah, memperingatkan, bertanya, melarang, menasihati, mendorong, memohon, mengizinkan, menyarankan, mengajak, meminta, dan mengkomando. Persamaan penelitian yang dilakukan oleh Yuliarti et al. dengan penelitian yang akan dilakukan adalah sama menggunakan teori tindak tutur direktif sedangkan perbedaannya adalah penelitian ini hanya berisi satu teori mengenai tindak tutur direktif yang ada pada bahasa tulis dan penelitian yang akan dilakukan adalah menggunakkan dua teori yaitu teori tindak tutur direktif dan bahasa lisan.

Penelitian mengenai bahasa lisan pernah dilakukan oleh Setyawan et al. (2014) meneliti tentang Bahasa Lisan Dalam Kegiatan Pembelajaran Siswa Kelas XI SMA Negeri I Sekincau, dengan hasil penelitian berupa bahasa lisan yang digunakan oleh siswa ditemukan sebanyak 25 untuk ragam resmi dan pilihan kata sebanyak 12, lafal sebanyak 4 kata, dan kalimat efektif sebanyak 10 kalimat. Persamaan penelitian ini dengan penelitian yang akan dilakukan adalah sama menggunakan teori bahasa lisan sedangkan perbedaaanya adalah penelitian yang dilakukan oleh Setyawan et al. hanya menggunakan teori bahasa lisan tanpa mengikutsertakan teori tindak tutur direktif dan pada hasil penelitian tidak fokus pada ciri linguistik bahasa lisan melainkan secara umum. 
Mengaca pada penelitian terdahulu belum adanya penelitian tentang tindak tutur direktif pada apoteker dan pasien dan juga belum adanya penelitian yang menyatukan dua teori mengenai tindak tutur direktif dan bahasa lisan dalam satu penelitian, sehingga penelitian ini perlu dilakukan agar memberikan edukasi atau pengetahuan kepada para pembaca bahwa dua teori ini dapat bersanding dalam satu penelitian. Dan tujuan dari penelitian ini adalah mendekripsikan jenis tindak tutur direktif yang dilakukan oleh apoteker dan pasien pada saat konseling dan juga mendeskripsikan ciri linguistik yang digunakan dalam bahasa lisan antara apoteker dan pasien dalam melakukan konseling di puskesmas Sukabumi.

\section{METODE PENELITIAN}

Penelitian ini termasuk penelitian kualitatif menggunakan pedekatan deksriptif. Penelitian kualitataif adalah penelitian yang memiliki tujuan untuk mengetahui fenomena-fenomena yang ada pada masyarakat atau sosial dengan menggunakan gambaran yang lengkap dan rinci yang kemudian dapat tersaji berupa kata yang diperoleh dari informan yang terjadi secara alamiah (Fadli, 2021). Dengan demikian penelitian kualitatif dijadikan sarana untuk menemukan fenomena yang terfokus pada tindak tutur direktif dan ciri linguistik bahasa lisan. Pendekatan deskriptif digunakan untuk mendeskripsikan fenomena yang ditemukan.

Sumber data yang digunakan adalah kata atau kalimat yang dilontarkan oleh pasien dan apoteker yang sedang melakukan konseling di puskesmas Sukabumi yang diundung di laman dalam jaringan Youtube. Sedangkan data yang digunakan yaitu kutipan yang berupa kata atau kalimat antara pasien dan apoteker dalam proses konseling yang masih relevan dengan teori tindak tutur direktif dan ciri linguistik bahasa lisan. Penelitian ini menggunakan teknik pengumpulan berupa mengunduh video konseling di Youtube, membuat transkripsi tuturan antara apoteker dan pasien, dan mengelompokkan kata atau bahasa dari hasil transkripsi sesuai dengan indikator penelitian tindak tutur direktif dan bahasa lisan. Hasil temuan kemudian dianalisis dan dideskripsikan sesuai dengan teori tindak tutur direktif dan ciri linguistik bahasa lisan, yang kemudian hasil deksripsi ditarik kesimpulan dan dijadikan sebagai artikel penelitian.

\section{PEMBAHASAN}

\section{Bentuk tindak tutur direktif dalam konseling antara apoteker dan pasien di puskesmas Sukabumi}

Hasil analisis data dalam kegiatan konseling antara pasien dan apoteker di puskesmas Sukabumi pada tahun 2020, ditemukan tindak tutur direktif yang digunakan ada 4 jenis yaitu: menyuruh, memohon, menyarankan, dan menasihati. Tindak tutur yang digunakan oleh apoteker memiliki tujuan dan konteks yang berbeda pada setiap data berikut beserta penjelasannya:

\section{Tindak Tutur Direktif Menyuruh}

Tindak tutur direktif ada beberapa jenis, jenis yang pertama adalah jenis meyuruh. Tindak tutur menyuruh identik berisi dengan permintaan dari penutur untu mitra tutur 
untuk melakukan suatu hal, baik untuk kepentingan pribadi maupun kepentingan orang lain. Berikut data yang ditemukan mengenai tindak tutur direktif menyuruh:

(1) Apoteker: Bapak harus rajin olahraga

Data (1) di atas yaitu pada saat apoteker menanyakan perihal olahraga kepada pasien pertama, pasien pertama tersebut menjawab tidak suka olahraga sehingga apoteker meminta atau menyuruh sang pasien untuk lebih rajin olahraga. Data di atas masuk ke dalam tindak tutur direktif menyuruh karena pada tuturan di atas memiliki makna perintah mengenai permintaan untuk rajin olahraga yang dikeluarkan atau dituturkan oleh penutur yaitu apoteker kepada mitra tutur yaitu pasien tersebut.

(2) Apoteker: ini harus rutin diminum

Data (2) di atas merupakan data dari tindak tutur direktif menyuruh, dikatakan jenis menyuruh karena dari tuturan di atas memiliki makna berupa permintaan untuk rutin dalam mengonsumsi obat yang telah diresepkan. Tuturan ini dituturkan oleh apoteker kepada mitra tuturnya yaitu pasien yang datang. Data di atas memiliki kata penegasan pada kata "harus", yang juga bisa dikatakan bahwa tuturan di atas merupakan tuturan perintah. Oleh sebab itu dapat disimpulkan bahwa data di atas benar bentuk dari tindak tutur direktif menyuruh dengan penguatan makna yang terkadung dan kata penegas yaitu "harus".

\section{Tindak Tutur Direktif Memohon}

Jenis tindak tutur direktif yang kedua adalah memohon, memohon adalah kegiatan yang melibatkan penutur yang meminta mitra tutur untuk melakukan hal atau kegiatan yang diminta penutur dengan proses atau keadaan yang lebih mengutamakan kesopanan. Berikut data mengenai tindak tutur direktif memohon:

(3) Apoteker: saya boleh minta waktu bapak sekitar tujuh sampai 10 menit.

Data (3) merupakan data dari jenis tindak tutur direktif memohon. Karena makna yang terkadung dalam tuturan di atas adalah perihal permintaan yang diajukan dengan hormat mengenai waktu oleh penutur yaitu apoteker kepada mitra tutur yaitu pasien. Pada tuturan di atas memiliki titik kesopanan pada kalimat "boleh minta waktu". Dengan demikian dapat disimpulkan bahwa tuturan di atas benar adanya merupakan data dari tindak tutur direktif jenis memohon dengan penguat makna yang terkandung dengan disertai kesopanan di dalamnya dan juga terdapat kalimat bukti mengenai adanya kesopanan berupa "boleh minta waktu".

(4) Apoteker: ini kan obatnya cuma dua bapak diharapkan patuh, mengonsumsinya setiap hari ya pak 
Data (4) di atas merupakan data dari tindak tutur direktif jenis memohon. Tuturan di atas memiliki makna permintaan yang dikeluarkan oleh penutur yaitu apoteker kepada mitra tutur yaitu pasien mengenai permintaan agar mitra tutur patuh dalam mengonsumsi obat setiap harinya dengan permintaan yang sopan. Terdapat kalimat kunci yang mencerminkan bahwa tuturan di atas terdapat unsur kesopanan yaitu pada kalimat "diharapkan patuh". Dapat ditarik benang merah berupa tuturan di atas merupakan tuturan jenis memohon dengan melihat makna yang terkadung dalam tuturan yang melibatkan kesopanan di dalamnya, disertai dengan kalimat pendukung yang mencerminkan keseponan yaitu "diharapkan patuh".

\section{Tindak Tutur Direktif Menyarankan}

Jenis tindak tutur direktif yang ketiga adalah menyarankan. Menyarankan adalah kegiatan penutur memberikan kalimat dengan tujuan baik untuk mitra tutur maupun bagi penutur. Berikut data mengenai tindak tutur direktif menyarankan:

(5) Apoteker: Nah terus bapak bisa langsung berkonsultasi kepada dokter atau bapak bisa langsung menghubungi saya di sini di puskesmas

Data (5) di atas merupakan data dari tindak tutur direktif jenis menyarankan. Tindak tutur di atas merupakan tindak tutur yang dituturkan oleh apoteker kepada mitra tuturnya yaitu pasien. Tuturan di atas memiliki makna pemberian saran mengenai kesehatan pasien, apoteker menyarankan jika tidak langsung berkonsultasi kepada dokter, maka pasien tersebut bisa menghubungi apoteker saja. Data (5) di atas dapat dibuktikan bahwa termasuk ke dalam jenis menyarankan yang terlihat dari segi makna yang terkandung dalam tuturan di atas.

\section{Tindak Tutur Direktif Menasihati}

Jenis tindak tutur direktif keempat atau yang terakhir adalah menasihati. Menasihati adalah kegiatan yang melibatkan penutur dalam memberikan nasihat atau pembelajaran baik dan bisa juga berisi anjuran yang baik kepada mitra tutur

(6) Apoteker: alangkah baiknya bapak mengurangi mengonsumsi garam

Data (6) merupakan data pertama dari tindak tuttur direktif jenis menasihati. Tindak tutur ini memiliki makna berupa anjuran baik yang diberikan oleh penutur yaitu apoteker kepada mitra tutur yang sedang memberikan nasihat kepada pasiennya untuk mengurangi konsumsi garam. Terdapat kalimat yang bisa mencerminkan bahwa data tersebut adalah data dari jenis menasihati yaitu pada kalimat "alangkah baiknya" yang mengisyaratkan kalimat nasihat dari penutur yang diberikan kepada mitra tutur.

(7)) Apoteker: nanti kalau bapak mengalami gejala batuk yang sampai mengganggu karena mengonsumsi obat ini, nanti sebaiknya bapak hentikan dulu 
Data (7) merupakan data kedua dari jenis menasihati dengan tanda kata "sebaiknya". Kata "sebaiknya" adalah bentuk adjektiva yang memiliki arti sepantasnya atau sepatutnya, dapat diartikan secara istilah yaitu sang apoteker memberi nasihat kepada pasien agar melakukan hal yang dikatakan. Dan dapat disimpulkan bahwa data di atas merupakan data dari tindak tutur direktif jenis menasihati dengan melihat makna yang terkandung yaitu anjuran baik mengenai saran jika terdapat kondisi yang mengganggu yang dialami mitra tutur atau pasien.

Berdasarkan hasil penelitian dalam kegiatan konseling antara apoteker dan pasien di puskesmas Sukabumi pada tahun 2020 ditemukan 4 jenis tindak tutur direktif yaitu tidak tutur direktif menyuruh, tindak tutur direktif memohon, tindak tutur direktif menyarankan, dan tindak tutur menasihati. Tindak tutur yang dilakukan oleh apoteker memiliki tujuan yang berbeda dalam proses konseling yaitu sebagai berikut:

Pertama: tindak tutur direktif menyuruh. Dalam hasil analasis yang terdapat dalam proses konseling antara pasien dan apoteker terdapat tindak tutur direktif menyuruh hal ini bertujuan untuk meminta mitra tutur untuk melakukan suatu hal.

Kedua: tindak tutur direktif memohon. Tidak tutur direktif memohon lebih halus daripada tindak tutur direktif menyuruh karena hal ini penutur tidak serta merta meminta mitra tutur untuk melakukan hal tersebut. Hal ini bertujuan agar mitra tutur merasa nyaman dengan apa yang disampaikan oleh penutur, yaitu dengan melibatkan unsur kesopanan di dalamnya.

Ketiga: tindak tutur direktif menyarankan. Tindak tutur ini memiliki tujuan untuk memberikan hal yang tentunya baik untuk mitra tutur apabila hal yang dilakukannya sesuai dengan yang dikatakan oleh penutur.

Keempat: tindak tutur direktif menasihati. Tindak tutur direktif menasihati yang terdapat dalam data dalam proses konseling antara pasien dan apoteker memiliki tujuan berupa hal yang diminta atau dikatakan oleh penutur pasti memiliki manfaat bagi mitra tutur dan juga untuk penutur pribadi.

Dari hasil penelitian di atas dapat disimpulkan bahwa dalam kegiatan konseling antara pasien dan apoteker ditemukan 4 jenis tindak tutur direktif yaitu menyuruh dengan tujuan meminta mitra tutur untuk melakukan suatu kegiatan atau hal, memohon dengan tujuan meminta mitra tutur melakukan sesuatu dengan melibatkan unsur kesopanan di dalamnya, menyarankan dengan tujuan memberikan saran kepada mitra tutur, dan menasihati dengan tujuan memberikan nasihat atau anjuran baik kepada mitra tutur. Berbeda dengan penelitian yang dilakukan oleh Elmita et al. (2013) yang ditemukan hasil penelitian mengenai tindak tutur direktif dengan 5 jenis yaitu jenis menyuruh menggunakan kata kunci "coba", tuturan jenis memohon dengan menggunakan kata kunci "bisa", tuturan menyarankan memiliki kata kunci "bisa", tuturan menasihati memiliki kata kunci "tidak boleh" dan tindak tutur menantang dengan kata kunci "siapa yang tahu?".

Jika dibandingkan kedua hasil di atas maka terlihat dalam penelitian yang dilakukan Elmita et al. (2013) bahwa penelitian tersebut tidiak mengemukakan tujuan dari tindak tutur yang dituturkan, hanya berisikan dengan kata kunci yang menunjukkan jika kalimat 
tersebut benar masuk ke dalam tuturan direktif. Sedangkann pada penelitian ini, terdapat tujuan yang disertai dengan kata kunci yang terdapat di dalamnya.

\section{Bentuk ciri linguistik bahasa lisan pada proses konseling antara apoteker dan pasien}

Hasil analisis data dari bahasa lisan yang memiliki beberapa ciri linguistik yang ditemukan pada saat proses konseling antara apoteker dan pasien di puskesmas Sukabumi pada tahun 2020 yaitu: Kalimat tidak lengkap (tidak menyertakan subjek, objek dan predikat), Frasa-frasa sederhana, beberapa kalimat sering diulang, dan bahasa tidak baku.

\section{Kalimat tidak Lengkap (tidak Menyertakan Subjek, Predikat dan Objek)}

Bahasa lisan memiliki beberapa ciri linguistik salah satunya adalah ciri linguistik berupa kalimat tidak lengkap dengan tidak menyertakan fungsi objek atau predikat atau subjek. Dengan data yang ditemukan sebagai berikut:

(8) Pasien: Herdi Ruswandi

Data (8) merupakan data pertama yang datang dari jawaban yang disebutkan oleh pasien pada saat ia menyebut namanya yaitu pada kata " Herdi Ruswandi" sebenarnya terdapat pelesapan atau bisa juga disebut sebagai tidak menyertakan fungsi subjek dan predikat. Dapat dituliskan dengan "saya bernama Herdi Ruswandi" kata "saya" menduduki fungsi subjek, kata "bernama" menduduki fungsi predikat dan barulah nama yang disebutkan atau "Herdi Ruswandi" merupakan fungsi objek dari kalimat yang dikatakan sebelumnya. Oleh sebab itu, dapat dibuktikan bahwa proses konseling antara pasien dan apoteker menggunakan bahasa lisan karena terdapat ciri linguistik dari bahasa lisan dengan jenis kalimat tidak lengkap. Meskipun kalimat tidak lengkap yang dituturkan oleh penutur maupun mitra tutur. Akan tetap saling memahami satu sama lain karena dibantu oleh unsur nonlinguistik lainnya.

\section{(9) Pasien: Sudajaya Baros}

Data (9) merupakan data kedua dari ciri linguistik bahasa lisan jenis kalimat tidak lengkap adalah data di samping yaitu "Sudajaya Baros". Apabila pasien ini tidak melakukan proses bahasa lisaan maka orang lain tidak akan paham maksud yang diberikan oleh pasien tersebut. kalimat yang harus digunakan oleh pasien jika pasien tidak melakukan bahasa lisan adalah "alamat saya di Sudajaya Baros", "Alamat" menempati fungsi predikat, "saya" menempati subjek, dan barulah "di Sudajaya Baros" merupakan frasa preposisional yang menduduki fungsi objek.

\section{Frasa-Frasa Sederhana}


Ciri linguistik dari bahasa lisan yang kedua adalah terdapat frasa-frasa sederhana. Karena bahasa lisan harus digunakan oleh dua orang atau lebih yang sedang berinteraksi satu sama lain, sehingga ada kalanya salah satu penutur atau mitra tutur menjawab hanya dengan menggunakan frasa sederhana.

(10) Pasien: ga ada

Data (10) merupakan data pertama dari ciri lingusitik frasa sederhana yaitu pada frasa "ga ada". Frasa di samping termasuk juga bisa termasuk ke dalam ciri linguistik bahasa lisan jenis kata tidak baku. Frasa "ga ada" dalam bahasa baku akan berbunyi "tidak ada". Frasa "Tidak ada" adalah bentuk frasa verbal. Dengan makna penolakan akan keberadaan suatu hal. Tergantung konteks yang sedang ditanyakan atau konteks yang dinyatakan oleh penutur sebelumnya yaitu sang apoteker. Dan dapat disimpulkan bahwa frasa "tidak ada" merupakan salah satu ciri linguistik dari bahasa lisan yang wajar digunakan oleh penutur atau mitra tutur dalam menggunakan bahasa lisan.

(11) Pasien: Resep pertama kali

Data (11) dia tas merupakan data dari ciri linguistik bahasa lisan dengan jenis terdapat frasa sederhana. Yaitu pada frasa 'resep pertama kali" frasa tersebut termasuk ke dalam frasa nominal dengan kunci kata "resep". Frasa ini disebutkan oleh pasien pada saat ditanya mengenai obat yang diresepkan oleh dokter. Data tersebut membuktikan bahwa proses kegiatan konseling antara apoteker dan pasien menggunakan bahasa lisan dengan data terdapat frasa sederhana.

(12) Pasien: sesudah makan

Data (12) dari tuturan pasien dalam bentuk frasa sederhana "sesudah makan" dari frasa tersebut memiliki kunci utama pada kata "makan" maka data tersebut dikatakan frasa nominal karena kata "makan" merupakan kata nomina. Frasa tersebut dikatakan oleh pasien pada saat dia diberikan pilihan jam minum obat pada sebelum atau sesudah makan dan pasien tersebut menjawab sesudah makan. Apabila disuguhkan hanya frasa tersebut maka seorang tidak akan paham apa maksud dari perkataan tersebut. sehingga dapat disimpulkan bahwa frasa "sesudah makan" merupakan frasa nominal yang bisa mewaili ciri linguistik dari bahasa lisan jenis frasa sederhana.

\section{Kalimat yang Sering Diulang}

Ciri linguistik selanjutnya pada bahasa lisan adalah terdapat kalimat yang sering diulang, ada berbagai macam faktor yang mengakibatkan ciri linguistik ini terjadi. Berikut data mengenai kalimat sering di ulang:

(13) Apoteker: yang pertama itu ada obat darah tinggi ya, yang ini, nah yang ini 
Data (13) merupakan data dari ciri linguistik bahasa lisan jenis kalimat sering diulang. Terletak pada kalimat "yang ini”. Kata "yang ini” dikatakan oleh sang apoteker yang kemudian diulang karena pada saat berbicara apoteker mencari obat yang sesuai dengan obat apa yang akan dibicarakan. Oleh sebab itu dapat disimpulkan bahwa kata "yang ini" merupakan ciri linguistik dari bahasa lisan karena kata tersebut mengalami pengulangan, yang disebabkan penutur atau apoteker mencari obat atau membutuhakn waktu untuk mencari obat yang akan ditunjukkan kepada mitra tuturnya yaitu pasien.

(14) Pasien: boleh boleh

Data (14) merupakan salah satu ciri linguistik bahasa lisan dari pengualangan adalah pada kata "boleh". Karena hanya satu kata yang diulang bukan berarti ini termasuk reduplikasi karena dalam KBBI tidak terdapat model reduplikasi dari kata boleh yang tidak melibatkan afiks, sufiks maupun prefiks. Sehingga dapat disimpulkan bahwa kata "boleh" yang dikatakan oleh pasien merupakan data dari ciri linguistik pengulangan yang menandakan bahwa pasien dan apteker benar menggunakan bahasa lisan.

\section{Bahasa tidak Baku}

Ciri linguistik terakhir dari bahasa lisan ialah bahasa yang digunakan tidak baku, bahasa melliputi kata atau frasa bahkan bisa saja keseluruhan kalimat yang tidak baku.

(15) Apoteker: ngobrol-ngobrol ya

Data (15) ialah data pertamadari bahasa tidak baku yang terdapat pada kata 'ngobrol' dalam KBBI kata "ngobrol" tidak ditemukan. Kata asli yang seharusnya diucapkan oleh apoteker adalah "mengobrol" dari asal kata "obrol" mengobrol adalah bentuk kata kerja dengan mengalami imbuhan MeN-. Sehingga dapat disimpulkan bahwa kata "ngobrol" adalah kata tidak baku.

(16) Apoteker: trus setelah minum itu gimana rasanya?

Data (16) dari perkataan apoteker terletak pada kata "gimana". Dalam KBBI kata "gimana" tidak ditemukan, kata tidak baku "gimana" ialah kata tanya yang menanyakan tentang proses, cara dan sebagainya. Sama halnya dengan kata "bagaimana". Kata bagaimana seharusnya digunakan oleh apoteker untuk menanyakan kepada pasiennya karena kata yang baku yaitu "bagaimana" bukan "gimana". Dapat disimpulkan bahwa proses konseling yang dilakukan oleh apoteker dan pasien menggunakan bahasa lisan, karena terdapat bahsa tidak baku yang terlibat dalam percakapan keduanya.

Dalam menyampaikan suatu dalam wujud komunikasi dapat diutarakan dengan dua cara yaitu bahasa lisan dan bahasa tulis. Pada penelitian ini terfokus pada penggunaan bahasa lisan yang digunakan oleh apoteker dan pasien di puskesmas Sukabumi pada tahun 2020 yang termasuk pada ciri linguistik bahasa lisan. Dan dari 
hasil analisis data mengenai bahasa lisan yang digunakan oleh apoteker dan pasien terdapat tujuan sebagai berikut:

Pertama: kalimat tidak lengkap. Penggungaan kalimat tidak lengkap dengan menghilangkan fungsi subjek, predikat dan objek. Hal ini karena pada saat proses penggunaan bahasa lisan, terdapat unsur-unsur nonlinguistik pendukungnya, yaitu tergantung tinggi rendahnya intonasi suara lawan.

Kedua: frasa-frasa sederhana. Hal ini sering muncul karena jika menggunakan bahasa lisan cukup untuk menjawab kata yang ditanyakan atau dinyatakan oleh lawan tutur sehingga pengulangan tidak diperlukan dalam bahasa lisan.

Ketiga: kalimat sering diulang. Kalimat sering diulang karena pada proses menggunakan bahasa lisan pengguna atau penutur bisa saja sedang berfikir kalimat yang cocok atau pas untuk digunakan untuk melanjutkan pembicaraannya, dan bisa juga dikarenakan oleh membutuhkan waktu dalam menjelaskan sesuatu dengan menunjukkan benda atau barang yang akan dijelaskan.

Keempat: kata tidak baku. Kata tidak baku dilakukan atau digunakan oleh seorang penutur karena telah biasa menggunakan bahasa tersebut sehingga bermula pada bahasa memiliki sifat arbitrer, oleh sebab itu bahasa yang digunakan tergantung dengan kebiasaan yang digunakan oleh penutur sendiri bahkan bisa juga dipengaruhi oleh masyarakat.

Dapat disimpulkan dalam penelitian ini menjabarkan ciri linguistik dalam bahasa lisan yaitu terdapat kalimat tidak lengkap, frasa-frasa sederhana, kalimat sering diulang dan terdapat kata tidak baku. Berbeda dengan penelitian sebelumnya yang dilakukan oleh Setyawan et al. (2014) mengenai bahasa lisan pada kegiatan pembelajaran di sekolah tidak menjabarkan mengenai ciri linguistik, akan tetapi hasil yang didapat berupa beberapa pilihan kata ragam bahasa lisan resmi yang digunakan terdapat 25 kata. Sama halnya dengan penelitian yang dilakukan oleh Aisah, S., \& Noviadi (2018) ditemukan hasil penelitian dari bahasa lisan yang terdapat pada pedagang buah pada Langensari, berupa jenis bahasa lisan berisikan dialek jawa dan dialek sunda. Sejauh ini belum terdapat penelitian yang mendeskripsikan ciri linguistik dari bahasa lisan. Sehingga dengan adanya penelitian ini menambah wawasan bagi para pembaca mengenai ciri linguistik dari bahasa lisan.

\section{SIMPULAN}

Dilihat dari tujuan penelitian ini adalah mendeskripsikan tindak tutur direktif yang digunakan oleh apoteker pada saat konsultasi dengan pasien di puskesmas sukabumi. Dalam penelitian ini ditemuka 4 jenis tindak tutur direktif yaitu: menyuruh dengan tujuan meminta mitra tutur untuk melakukan sesuatu, memohon dengan tujuan meminta mitra tutur melakukan sesuatu akan tetapi meminta dengan disertai rasa hormat, menyarankan 
dengan tujuan memberikan saran atau anjuran kepada mitra tutur dan menasihati dengan tujuan memberikan nasihat kepada mitra tutur

Tujuan kedua penelitian ini adalah mendeskripsikan ciri linguistik bahasa lisan yang ada pada proses konseling antara apoteker dan pasien yaitu diperoleh 4 ciri linguistik berupa kalimat tidak lengkap (tidak menyertakan subjek, objek dan predikat), Frasa-frasa sederhana, beberapa kalimat sering diulang, dan bahasa tidak baku.

\section{REFERENSI}

Aisah, S., \& Noviadi, A. (2018). Ragam Bahasa Lisan Para pedagang Buah Pasar Langensari Kota Banjar. Literasi: : Jurnal Bahasa Dan Sastra Indonesia Serta Pembelajarannya, 2(1), 83.

Elmita, W., Ermanto, \& Ratna, E. (2013). Tindak Tutur Direktif Guru Dalam Proses Belajar Mengajar di TK Nusa Indah Banuaran Padang. Jurnal Pendidikan Bahasa Dan Sastra Indonesia, 1(2), 139-147.

Fadli, M. R. (2021). Memahami desain metode penelitian kualitatif. Humanika, 21(1), 33-54. https://doi.org/10.21831/hum.v21i1.38075

Januar, P. (2014). Ragam Bahasa Lisan Dan Tulisan Siswa Kelas X Jurusan Akomodasi Perhotelan Smk Negeri 3 Bogor Tahun Pelajaran 2013-2014. Lokabasa, Vol 5(No 1), 4753. ejournal.upi.edu/index.php/lokabasa/article/view/3156/2176\%0D

Apriastuti, N.N.A.A. (2017). Bentuk, Fungsi Dan Jenis Tindak Tutur Dalam Komunikasi Siswa Di Kelas Ix Unggulan Smp Pgri 3 Denpasar. Jurnal Ilmiah Pendidikan Dan Pembelajaran, 1(1), 38-47.

Arifiany, N, Ratna, M. P. (2016). Pemaknaan Tindak Tutur Direktif Dalam Komik "Yowamushi Pedal Chapter 87-93." Journal of Chemical Information and Modeling, 2(1), 1-11.

Purba, A. (2011). Tindak tutur dan peristiwa tutur. 1(1), 77-91.

Qomariyah, L. (2017). Tindak Tutur Direktif Guru Dalam Pembelajaran Bahasa Arab. Arabi : Journal of Arabic Studies, 2(1), 1. https://doi.org/10.24865/ajas.v2i1.32

Rahma, A. N. (2018). Analisis tindak tutur ilokusi dalam dialog film animasi. 2(2), 13-24.

Sagita, V. R., \& Setiawan, T. (2020). Tindak Tutur Ilokusi Ridwan Kamil dalam "Talkshow Insight" di CNN Indonesia (The Form and Type of Illocutionary Speech Acts Ridwan Kamil in the "Insight Talkshow" at CNN Indonesia). Lensa: Kajian Kebahasaan, Kesusastraan, Dan Budaya, 9(2), 187. https://doi.org/10.26714/lensa.9.2.2019.187-200

Saragih, D. K. (2013). Bahasa dan Ragam Bahasa pada Pendidikan Anak Sekolah. Journal of Chemical Information and Modeling, 53, 1-11. 
Setyawan, A., Suyanto, E., \& Agustina, E. S. (2014). Bahasa Lisan Dalam Kegiatan Pembelajaran Siswa Kelas Xi Sma Negeri I Sekincau. Jurnal Kata (Bahasa, Sastra, Dan Pembelajarannya), 1-9.

Stambo, R., \& Ramadhan, S. (2019). Tindak Tutur Ilokusi Pendakwah Dalam Program Damai Indonesiaku di TV One. Basindo, 3, 250-260.

Suryatin, E. (2018). Tindak Tutur Direktif Bahasa Indonesia Pada Poster Kesehatan Di Puskesmas Kota Banjarbaru. Undas, 14(1), 117-128.

Yuliarti, R, \& Nuryatin, A. (2015). Tindak Tutur Direktif Dalam Wacana Novel Trilogi Karya Agustinus Wibowo. Seloka: Jurnal Pendidikan Bahasa Dan Sastra Indonesia, 4(2), 7885. 